\title{
A turbulent decade for NSAIDs: update on current concepts of classification, epidemiology, comparative efficacy, and toxicity
}

\author{
Philip G. Conaghan
}

Received: 16 May 2011/Accepted: 8 December 2011/Published online: 23 December 2011

(c) The Author(s) 2011. This article is published with open access at Springerlink.com

\begin{abstract}
Non-steroidal anti-inflammatory drugs (NSAIDs) represent a diverse class of drugs and are among the most commonly used analgesics for arthritic pain worldwide, though long-term use is associated with a spectrum of adverse effects. The introduction of cyclooxygenase-2-selective NSAIDs early in the last decade offered an alternative to traditional NSAIDs with similar efficacy and improved gastrointestinal tolerability; however, emerging concerns about cardiovascular safety resulted in the withdrawal of two agents (rofecoxib and valdecoxib) in the mid-2000s and, subsequently, in an overall reduction in NSAID use. It is now understood that all NSAIDs are associated with some varying degree of gastrointestinal and cardiovascular risk. Guidelines still recommend their use, but little is known of how patients use these agents. While strategies and guidelines aimed at reducing NSAID-associated complications exist, there is a need for evidence-based algorithms combining cardiovascular and gastrointestinal factors that can be used to aid treatment decisions at an individual patient level.
\end{abstract}

P. G. Conaghan $(\bowtie)$

Section of Musculoskeletal Disease,

Department of Musculoskeletal Medicine,

Leeds Institute of Molecular Medicine,

University of Leeds, 2nd Floor Chapel Allerton Hospital,

Chapeltown Road, Leeds LS7 4SA, UK

e-mail: p.conaghan@leeds.ac.uk

P. G. Conaghan

NIHR Leeds Musculoskeletal Biomedical Research Unit, Leeds, UK
Keywords Anti-inflammatory agents, non-steroidal · Cyclooxygenase-2 inhibitors - Comparative efficacy . Comparative safety

\section{Introduction}

Non-steroidal anti-inflammatory drugs (NSAIDs) are among the most commonly used drugs in the world [1, 2]. With demonstrated efficacy in the management of pain [3], they are a recommended therapy for the large population who suffer from osteoarthritis (OA) [4-7] and rheumatoid arthritis (RA) [8]. However, their chronic use is associated with a well-recognized spectrum of side effects, in particular those involving the gastrointestinal system [9] and, as highlighted by the relatively recent withdrawal of certain cyclooxygenase (COX)-2-selective agents (rofecoxib and valdecoxib), the cardiovascular system $[10,11]$.

There was subsequently a reduction in the prescribing of all NSAIDs [12, 13], re-thinking about the value of classifying drugs on COX selectivity alone, and increasing investigation into the relative toxicity profiles of NSAIDs. At the end of this rather turbulent decade for NSAIDs, it now seems timely to briefly review their classification, recent epidemiology of use, and the comparative efficacy and toxicity of different NSAIDs, with a focus on the gastrointestinal and cardiovascular risks that pose a major concern in practice.

For the purposes of this review, the terms non-selective (ns) and COX-2-selective will be used where appropriate, whereas the generic term NSAID will refer to all agents. Peer-reviewed, English-language articles were identified for inclusion in this review through searches of MEDLINE and selected on the basis of their relevance. Search terms included: NSAIDs, COX-2, efficacy, safety, 
tolerability, gastrointestinal, and cardiovascular, alone or in combination.

\section{Mechanism of action of NSAIDs}

The principle of NSAID therapy dates back to the use of willow bark more than 5,000 years ago for musculoskeletal pain $[14,15]$. The active ingredient of willow bark, salicin, was isolated in 1828 and the industrial production of salicylic acid underway by 1874 [14, 15]. Aspirin (acetylsalicylic acid) was developed in 1897 in an attempt to improve palatability $[14,15]$. Indomethacin and ibuprofen were among the first non-aspirin NSAIDs to be introduced in 1964 and 1969, respectively [14, 15]. Subsequently, many new classes of NSAIDs have followed, including diclofenac in 1974 and naproxen in 1976 [14, 15].

NSAIDs are a diverse group of drugs with common analgesic, anti-inflammatory, and anti-pyretic therapeutic properties [16]. The action of NSAIDs was first described in 1971 when Vane and Piper demonstrated that NSAIDs inhibit the biosynthesis of prostaglandins by preventing the substrate arachidonic acid from binding to the COX enzyme active site [17]. The COX enzyme was subsequently found to exist in two isoforms-COX-1 was characterized in 1976, and the gene for the COX-2 isoenzyme was later discovered in 1991 [17]. COX-1 is constitutively expressed and catalyzes the production of prostaglandins that are involved in numerous physiological functions, including maintenance of normal renal function in the kidneys, mucosal protection in the gastrointestinal tract, and pro-aggregatory thromboxane $\mathrm{A}_{2}$ in the platelets $[17,18]$. By contrast, COX-2 expression can be induced by cytokines and other inflammatory mediators in a number of tissues, including endothelial cells, and is believed to have a role in the mediation of pain, inflammation, and fever $[16,17]$. There has been speculation on the existence of a third isoform, COX-3, which would explain the mechanism of action of acetaminophen, a poor inhibitor of COX-1 and COX-2. Splice variants of COX-1 and COX-2 have emerged that have been referred to as $\mathrm{COX}-3$ but have transpired to have little relevance in humans [19].

\section{Classification of NSAIDs}

NSAIDs can be classified according to numerous characteristics, including COX selectivity, and chemical and pharmacological properties (Table 1). NSAIDs generally have chemical similarity in that they are relatively lipidsoluble, weak acids. There are, however, some clinically relevant differences in pharmacokinetic properties [20].

NSAIDs generally have high bioavailability after oral administration. As a result of their chemical properties, they are well absorbed from the gastrointestinal tract and hepatic clearance is low [20]. However, the rate of absorption varies between NSAIDs, which can impact upon the suitability of different NSAIDs for particular indications [20]. NSAIDs can also be categorized by halflife into two groups: those with a short half-life $(<6 \mathrm{~h})$ and

Table 1 Classification of selected NSAIDs by COX-2 selectivity, chemical and pharmacokinetic properties [18, 111-115]

\begin{tabular}{|c|c|c|c|c|c|c|c|c|c|c|}
\hline NSAID & $\begin{array}{l}\text { COX-2 } \\
\text { selectivity } \\
\text { (SI) }\end{array}$ & $\begin{array}{l}\text { Chemical } \\
\text { structure }\end{array}$ & $\begin{array}{l}\text { Bioavailability } \\
(\%)\end{array}$ & $\begin{array}{l}\text { Half- } \\
\text { life } \\
(\mathrm{h})\end{array}$ & $\begin{array}{l}\text { Volume of } \\
\text { distribution }\end{array}$ & Clearance & $\begin{array}{l}\text { Peak } \\
\text { (h) }\end{array}$ & $\begin{array}{l}\text { Protein } \\
\text { binding } \\
(\%)\end{array}$ & $\begin{array}{l}\text { Renal } \\
\text { elimination } \\
(\%)\end{array}$ & $\begin{array}{l}\text { Clinical } \\
\text { dose } \\
(\mathrm{mg} / \mathrm{d})^{\mathrm{a}}\end{array}$ \\
\hline Ibuprofen & $\begin{array}{l}\text { Non-selective } \\
(1.05)\end{array}$ & $\begin{array}{l}\text { Propionic } \\
\text { acid }\end{array}$ & $>80$ & 2 & $0.15 \mathrm{~L} / \mathrm{kg}$ & $3.0-3.5 \mathrm{~L} / \mathrm{h}$ & $1-2$ & 99 & $45-79$ & $1,200-3,200$ \\
\hline Diclofenac & $\begin{array}{l}\text { Non-selective } \\
(1.97)\end{array}$ & $\begin{array}{l}\text { Acetic } \\
\text { acid }\end{array}$ & $50-60$ & 2 & $0.1-0.2 \mathrm{~L} / \mathrm{kg}$ & $21.0 \mathrm{~L} / \mathrm{h}$ & 2 & $>99$ & 65 & $100-150$ \\
\hline Naproxen $^{\mathrm{b}}$ & $\begin{array}{l}\text { Non-selective } \\
(0.33)\end{array}$ & $\begin{array}{l}\text { Propionic } \\
\text { acid }\end{array}$ & 95 & $12-17$ & $0.16 \mathrm{~L} / \mathrm{kg}$ & $0.13 \mathrm{~mL} / \mathrm{min} / \mathrm{kg}$ & $2-4$ & $>99$ & 95 & $500-1,000$ \\
\hline Meloxicam & $\begin{array}{l}\text { Selective } \\
(>2.04)\end{array}$ & Oxicam & 89 & $15-20$ & $10 \mathrm{~L}$ & $0.4-0.5 \mathrm{~L} / \mathrm{h}$ & $4-5$ & 99 & 50 & $7.5-15.0$ \\
\hline Celecoxib & $\begin{array}{l}\text { Selective } \\
(7.70)\end{array}$ & Pyrazole & NS & 11 & $400 \mathrm{~L}$ & $27.7 \mathrm{~L} / \mathrm{h}$ & 3 & 97 & 27 & 200 \\
\hline Ketoprofen & $\begin{array}{l}\text { Non-selective } \\
(0.02)\end{array}$ & $\begin{array}{l}\text { Propionic } \\
\text { acid }\end{array}$ & 90 & 2.1 & $0.1 \mathrm{~L} / \mathrm{kg}$ & $6.9 \mathrm{~L} / \mathrm{h}$ & $\leq 2$ & $>99$ & 80 & $200-300$ \\
\hline Etoricoxib & $\begin{array}{l}\text { Selective } \\
(105.40)\end{array}$ & Bipyridine & $100 \%$ & 22 & $120 \mathrm{~L}$ & $50 \mathrm{~mL} / \mathrm{min}$ & 1 & 92 & 75 & 60 \\
\hline
\end{tabular}

SI COX-2-selectivity index (SI = ratio of COX-1 half maximal inhibitory concentration $\left[\mathrm{IC}_{50}\right] / \mathrm{COX}-2 \mathrm{IC}_{50}$ ), COX-2 cyclooxygenase-2, NS not specified, NSAID non-steroidal anti-inflammatory drug

a Standard clinical dose for OA

${ }^{b}$ Non-enteric coated 
those with a long half-life (Table 1). This provides a guide to dosing with short half-life NSAIDs (e.g., ibuprofen) generally administered every $6-8 \mathrm{~h}$ and longer half-life NSAIDs (e.g., naproxen and celecoxib) administered once or twice daily [20-23]. Rapid absorption is a desirable feature for patients using NSAIDs for immediate analgesic relief, but may not always be most appropriate for patients with chronic pain.

\section{Epidemiology of NSAID prescribing}

NSAIDs are among the most commonly used drugs worldwide, used by more than 30 million people every day [2]. More than 111 million prescriptions are written for NSAIDs in the USA annually, and they account for approximately $60 \%$ of the USA over-the-counter (OTC) analgesic market [1].

The most commonly used NSAIDs are diclofenac and ibuprofen, which account for almost $40 \%$ of global NSAID sales for OA [24] (Fig. 1). Excluding OTC use, ibuprofen and naproxen are the most commonly prescribed NSAIDs in the USA, while diclofenac prescription is more common in the UK [24]. Reasons for regional variation may not just relate to drug properties but may also include which NSAID was first to market in a particular region.

The introduction of COX-2-selective agents with improved gastrointestinal safety led to an overall increase in the use of NSAIDs. Using prescription claims data, a Canadian study observed that the overall number of NSAID prescriptions among patients aged over 65 years increased by $68 \%$ between March and November 2000 following the introduction of celecoxib and rofecoxib. This increase was almost entirely attributable to COX-2-

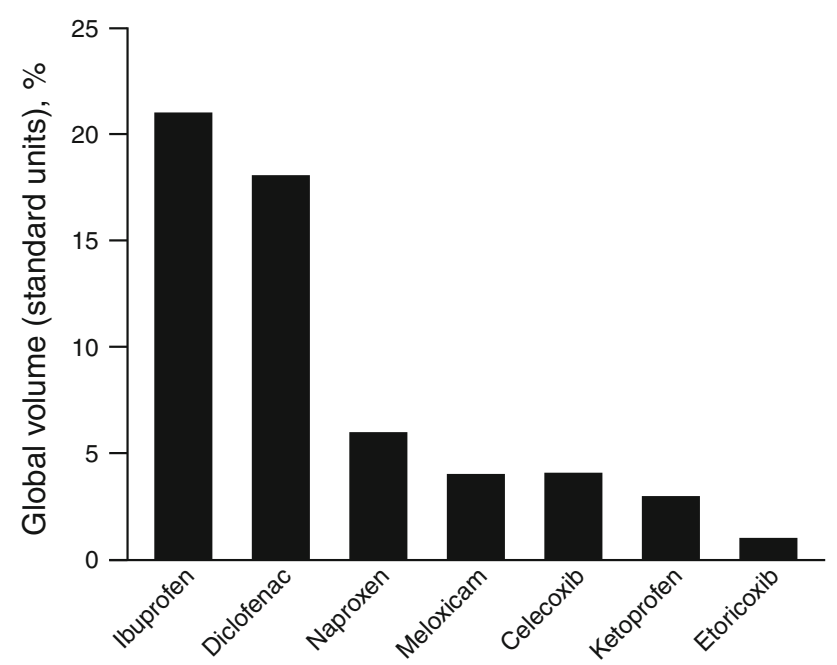

Fig. 1 Proportion of global sales for NSAIDs [24]. Adapted by permission from IMS Health, copyright 2008 selective agents as the level of nsNSAID prescribing remained relatively stable [25].

Following the withdrawal of rofecoxib and valdecoxib in the mid-2000s, there was a reduction in prescribing of all NSAIDs, primarily driven by marked decreases in the use of COX-2-selective agents that were not compensated by increases in nsNSAID use of the same magnitude. A prospective cohort study using American registry data found that the use of COX-2-selective agents decreased from 55.1 to $29.2 \%$ among patients with RA or psoriatic arthritis between 2003 and 2005. In contrast, use of nsNSAIDs increased from 50.2 to $73.9 \%$ [12]. Similarly, in Germany, COX-2selective agent prescriptions decreased by 37.1 million defined daily doses (DDDs) between 2004 and 2005, and nsNSAID prescriptions increased by 19.0 million DDDs [13]. This study reported an overall decrease in NSAID use of $8.4 \%$ [13]. It could be speculated that availability of generic COX-2-selective inhibitors in coming years following patent expiration will result in a resurgence in their use, although this remains to be seen.

\section{Use of NSAIDs by patients}

Use of NSAIDs, and in particular chronic use, increases with age, with an estimated $10-40 \%$ of people aged over 65 years using prescribed or OTC NSAIDs daily [26, 27]. In a survey of patients aged over 55 years with knee OA in two general practices in the UK, NSAIDs were used more commonly among patients from an affluent rural area compared with those from a deprived urban area [28]. There is also evidence to suggest that many patients use NSAIDs intermittently, as less than half receive prescriptions with enough medication to sustain longer-term daily use [29].

Use of OTC NSAIDs, generally available without prescription at lower doses, is also very common. A USA poll of more than 2,000 adults found that approximately 30\% use OTC analgesics on a regular basis for arthritis or some other form of chronic pain [30]. Based on the findings of the 1997 Roper survey commissioned by the American Gastroenterological Association and the 2002 National Consumer League study, with a combined total of 9,062 respondents, ibuprofen-based NSAIDs are the most widely used OTC NSAIDs, with the majority of patients using them on an as-needed basis [31]. The Roper study found that among prescription NSAID users, approximately $40 \%$ also use OTC NSAIDs at the same time [31].

Approximately one half of NSAID users in the Roper survey were not aware of the potential side effects. Among all NSAID users, $33 \%$ perceived prescription NSAIDs to be safer and $32 \%$ perceived OTC NSAIDs to be safer. Consumption of more than the recommended dose was 
more common among OTC NSAID users (26\%) than prescription NSAID users $(8 \%)$ [31].

\section{Comparative analgesic efficacy of NSAIDs}

NSAIDs have demonstrated short-term efficacy compared with placebo in the treatment of OA [3] (Fig. 2). The efficacy of NSAIDs has been further evaluated in a comparative effectiveness review for the Agency for Healthcare Research and Quality (AHRQ) Effective Healthcare Program [32], a drug effectiveness review project by the Oregon Health and Science University (OHSU), funded by the Center for Evidence-based Policy [33] and a UK National Health Service (NHS) health technology assessment [34].

Comparisons and meta-analyses of published studies have found that there are no clear differences in efficacy among nsNSAIDs at standard doses in the treatment of knee, back, or hip pain [32, 33]. Similarly, based on more than 20 randomized controlled trials and systematic reviews, the AHRQ review found that there are no significant differences in efficacy between COX-2-selective agents and nsNSAIDs [32]. In a review of previous systematic reviews of randomized controlled trials, the NHS health technology assessment found that COX-2-selective agents had equivalent efficacy to nsNSAIDs for the treatment of RA and OA [34]. Although sometimes based on data using supratherapeutic doses, celecoxib 200-800 mg/ day has efficacy equivalent to naproxen $1,000 \mathrm{mg} /$ day, diclofenac 100-150 mg/day, and ibuprofen 2,400 mg/day. Etoricoxib $60-120 \mathrm{mg} /$ day also has efficacy similar to naproxen $1,000 \mathrm{mg} /$ day, diclofenac $150 \mathrm{mg} /$ day, and ibuprofen 2,400 mg/day [34].

In randomized trials, celecoxib and nsNSAIDs have been found to be associated with similar levels of pain reduction in patients with OA, ankylosing spondylitis, and RA [33]. In the Successive Celecoxib Efficacy and Safety Study (SUCCESS), celecoxib 200-400 mg/day was found to have efficacy comparable to naproxen $1,000 \mathrm{mg} /$ day and diclofenac $100 \mathrm{mg} /$ day for the treatment of more than 13,000 patients with OA over 12 weeks [35].

The efficacy of etoricoxib and nsNSAIDs has also been compared in seven relatively small studies [34]. These studies found that etoricoxib 30-120 mg/day had comparable efficacy to naproxen, diclofenac, and ibuprofen at standard doses in patients with OA and RA [36-42]. In a more recent long-term study, etoricoxib 90-120 mg/day was found to have greater efficacy compared with naproxen $1,000 \mathrm{mg} /$ day over 12 weeks, but similar efficacy over 121 weeks [43].

Among COX-2-selective agents, the efficacy of rofecoxib $25 \mathrm{mg} /$ day, etoricoxib $30 \mathrm{mg} /$ day, and lumiracoxib 200 or $400 \mathrm{mg} /$ day has been compared with celecoxib $200 \mathrm{mg} /$ day. No significant differences for pain relief at these doses have been found [32, 44, 45].
Fig. 2 Efficacy of NSAIDs compared with placebo for the treatment of OA of the knee [3]. Knee OA studies 2-13 weeks in length. Adapted by permission from BMJ Publishing Group Limited (Bjordal JM et al. BMJ; 329: 1317, copyright 2004)

Celecoxib
Acetaminophen
Etodolac/naproxen
Rofecoxib
Naproxen/nabumetone
Etoricoxib
Valdecoxib/naproxen
Meloxicam
Nabumetone
Celecoxib/diclofenac
Etodolac/nabumetone
Lumiracoxib
Flurbiprofen
Nabumetone
Celecoxib
Etodolac
Celecoxib
Combined

\section{Number of patients}

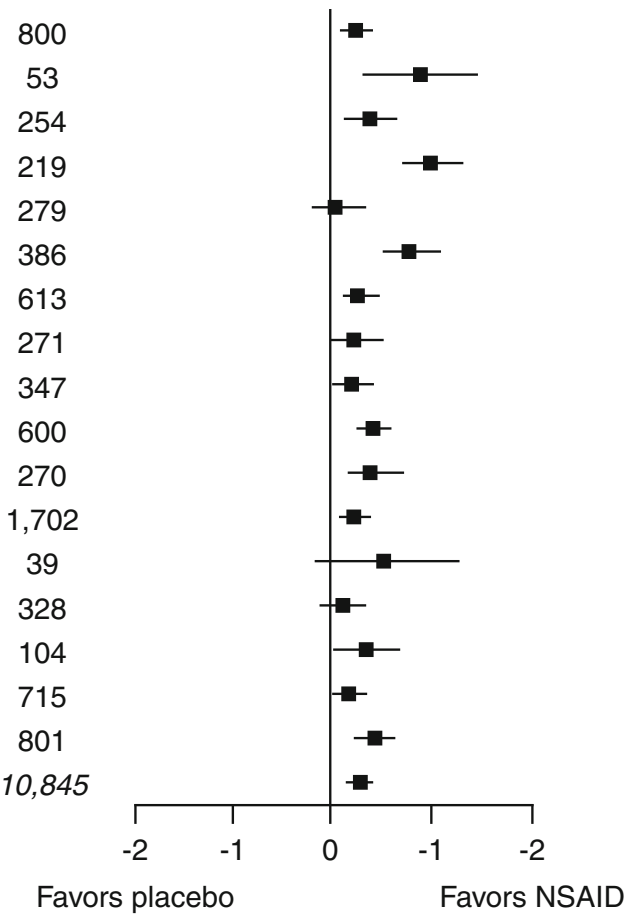

$P$-value

0.006

0.002

0.006

$<0.001$

0.733

$<0.001$

0.002

0.034

0.080

$<0.001$

0.002

0.003

0.119

0.351

0.053

0.015

$<0.001$

$<0.001$ 
How effective are NSAIDs in clinical practice?

The majority of clinical trials evaluating the analgesic efficacy of NSAIDs typically report outcomes as mean population changes. Such results can be difficult to translate for individual patients in clinical practice. In a recent study, data from seven randomized, controlled OA trials ( $\geq 6$ weeks' duration) assessing the efficacy of etoricoxib compared with other NSAIDs or placebo, using the Western Ontario and McMaster Universities Osteoarthritis Index (WOMAC), investigated this NSAID's effects on different levels of pain relief [46]. While $60-80 \%$ of patients experienced minimal pain relief $(\geq 15 \%$ improvement from baseline), only $20-30 \%$ experienced extensive pain relief ( $\geq 70 \%$ improvement from baseline).

\section{Comparative toxicity of NSAIDs}

Like many drugs, NSAIDs are associated with a broad range of side effects, including renal toxicity, exacerbation of hypertension, fluid retention, gastrointestinal complications, and cardiovascular events [15]. Furthermore, the presence of chronic co-morbidities in many, particularly elderly, patients with arthritis who require NSAIDs can be associated with increased risks of complications resulting in complex treatment decisions to balance risks and benefits [47].

\section{Gastrointestinal toxicity}

NSAIDs are associated with a spectrum of upper gastrointestinal complications, ranging from endoscopic ulcers in $10-30 \%$ of patients, to serious ulcer complications in 1-2\% of patients [48, 49], although the exact incidence is changing [50]. In recent years, the effect of NSAIDs on the lower gastrointestinal tract has begun to receive greater attention with opinion moving toward a focus on the complications affecting the whole gastrointestinal tract. At present, lower gastrointestinal complications are less well characterized but thought to be increasingly common [5052]. One systematic review reported the overall risk (OR) of lower gastrointestinal bleeding to be 1.9-18.4 in casecontrol studies [53].

In 1998, it was estimated that approximately 100,000 people were hospitalized annually in the USA as a result of NSAID-related gastrointestinal complications [54], and mortality is reported as approximately 5\% [55], which highlights the clinical importance of such events. Perhaps more importantly for people with arthritis who have few analgesic options, minor side effects (including symptoms of dyspepsia) occur in up to $60 \%$ of patients [49] and poor tolerability results in many patients discontinuing therapy
[56]. Management of gastrointestinal complications and dyspepsia adds significantly to the economic burden of arthritis [57].

A nested case-control study found that, compared with non-use, nsNSAIDs increased the risk of developing serious upper gastrointestinal complications by a factor of 3.7 (95\% confidence interval [CI] 3.1, 4.3), and COX-2selective agents by a factor of 2.6 (95\% CI 1.9, 3.6) [9]. Among individual NSAIDs, the relative risk (RR) of developing serious upper gastrointestinal complications compared with non-use ranged from 2.0 with ibuprofen to 12.0 with etoricoxib, though this was based on retrospective analyses that probably had an element of confounding by indication for the COX-2-selective agents. It has previously been reported that, based on meta-analyses from 1991 to 2004, the RR of serious gastrointestinal complications is 3-4-fold higher in nsNSAID users compared with non-users [58]. A more recent systematic review of observational studies reported that the RR for upper gastrointestinal bleeding or perforation varies between individual NSAIDs, ranging from 1.42 (95\% CI $0.85,2.37)$ with celecoxib to 14.54 (95\% CI 5.87, 36.04) with ketorolac (Fig. 3), and is influenced by NSAID half-life [59].

The majority of studies evaluating the gastrointestinal safety of NSAIDs have found that COX-2-selective inhibitors are associated with a lower risk of ulcers and complications than nsNSAIDs [35, 60-63]. However, in some studies, the difference in rate of all upper gastrointestinal clinical events and complicated events is not significant $[61,63]$. A 2008 review of randomized controlled trials and meta-analyses estimated that COX-2-selective agents are associated with $61 \% \mathrm{RR}$ reduction for ulcer

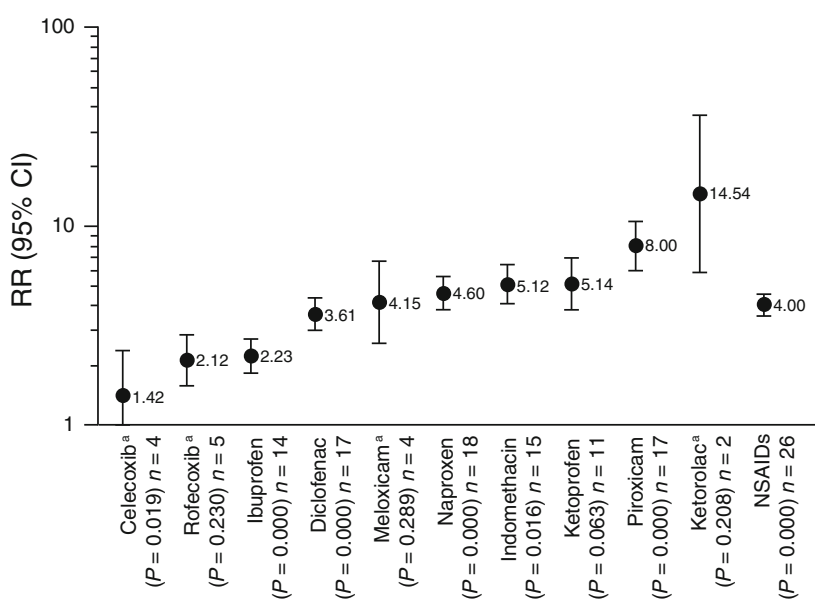

Fig. 3 Risk of upper gastrointestinal bleeding/perforation with individual NSAIDs from published studies since 1990 [59]. 'Studies published after 2000. $P$-values derived from heterogeneity test and $n$ (number of studies). Adapted by permission from John Wiley \& Sons, Inc (Massó González EL et al. Arthritis Rheum; 62: 1592, copyright 2010) 
complications compared with nsNSAIDs [64] and a separate systematic review of observational studies calculated that the RR for upper gastrointestinal bleeding or perforation was greater with nsNSAIDs (RR 4.50; 95\% CI 3.82, 5.31) than COX-2-selective agents (RR $1.88 ; 95 \%$ CI 0.96, 3.71) as a class, though it was noted that risk varied between individual NSAIDs [59].

There are a number of risk factors for NSAID-associated gastrointestinal injury, including high NSAID dose, older age, Helicobacter pylori infection, a history of ulcer or ulcer complications, and concomitant use of OTC NSAIDs, low-dose aspirin, anticoagulants, or corticosteroids [6567]. Concomitant use of low-dose aspirin for cardiovascular prophylaxis is common among NSAID users (approximately 20-25\% in clinical trials [62, 63, 68]) but increases the risk for mucosal damage $[69,70]$ and eliminates the gastrointestinal benefits of COX-2-selective agents [9, 62, 63]. For example, in a nested case-control study, García Rodríguez and Barreales Tolosa found that the RR of upper gastrointestinal complications was higher among patients using aspirin plus COX-2-selective agents (RR 1.9; 95\% CI 1.0, 3.6) compared with COX-2-selective agents alone (RR 0.6 ; 95\% CI 0.4, 0.9) [9].

NSAIDs, particularly diclofenac, nimesulide, and sulindac, are also associated with drug-related hepatotoxicity, as indicated by liver function test abnormalities in clinical trials and reports of fatal liver injury among NSAID users [71, 72]. Lumiracoxib, an analog of diclofenac, is a COX-2-selective inhibitor that was never approved in the USA and was withdrawn from the European market in 2007 as a result of concerns about potential liver toxicity [73].

\section{Cardiovascular toxicity}

NSAIDs are associated with an increased risk of cardiovascular adverse events such as myocardial infarction, heart failure, and hypertension [74], and this increase in risk appears to be dependent on duration of exposure [33]. It has been suggested that the mechanism for this may be the impact of COX inhibition on the balance between COX-2-mediated production of pro-aggregatory thromboxane in platelets and anti-aggregatory prostaglandin $I_{2}$ in endothelial cells $[18,75,76]$.

Previously, increasing COX-1 selectivity has been associated with an increased risk of gastrointestinal toxicity, while increasing COX-2 selectivity has been associated with an increased risk of cardiovascular toxicity [77]. It has since been suggested that this concept is flawed, as while COX-2-selective agents have varying but little effect on COX-1, COX-2-selective agents and nsNSAIDs both inhibit COX-2 at traditional therapeutic doses and have potential for cardiovascular toxicity. Therefore, COX selectivity alone is not sufficient to define the risk of NSAID-associated complications. Based on clinical evidence and an increased understanding of differences between individual NSAIDs, an alternative concept has been proposed that incorporates the association between increasing dose and NSAID-associated gastrointestinal and cardiovascular risk [77].

\section{COX-2-selective agents}

A meta-analysis comparing the effects of different COX-2selective agents found that there was a significant increase in the incidence of serious vascular events with COX-2selective agents compared with placebo (rate ratio 1.42; $95 \%$ CI $1.13,1.78 ; P=0.003$ ) that was primarily as a result of increased risk of myocardial infarction [78].

In the Vioxx Gastrointestinal Outcomes Research (VIGOR) study, it was observed that rofecoxib $50 \mathrm{mg} /$ day was associated with a fourfold increase in the incidence of myocardial infarction compared with naproxen $1,000 \mathrm{mg} /$ day in patients with RA [60]. The Adenomatous Polyp Prevention On Vioxx (APPROVe) study found that rofecoxib $25 \mathrm{mg} /$ day was associated with an increased RR of thrombotic events compared with placebo in patients with a history of colorectal adenomas after 18 months of treatment and an increased risk of myocardial infarction after 15 months of treatment [79]. Based on these findings, rofecoxib was withdrawn from the market in 2004. Valdecoxib was subsequently withdrawn in 2005 [80].

Cardiovascular safety data for celecoxib are available from three long-term trials: the Alzheimer's Disease Antiinflammatory Prevention Trial (ADAPT) [81], the Adenoma Prevention with Celecoxib (APC) study [82], and the Prevention of colorectal Sporadic Adenomatous Polyps (PreSAP) study [83]. Celecoxib 200-400 mg/day was associated with a significant and dose-related increase in death from cardiovascular causes in APC, but not in PreSAP or ADAPT [84]. However, based on an analysis of cardiovascular events in APC, all three studies were subsequently suspended [84]. In one systematic review, celecoxib was associated with a greater risk of myocardial infarction compared with placebo and nsNSAIDs [34], but another two concluded that the cardiovascular risk of celecoxib is generally similar to that with placebo or nsNSAIDs [84, 85].

The cardiovascular safety of etoricoxib 60 or $90 \mathrm{mg} /$ day was compared with diclofenac $150 \mathrm{mg} /$ day in a pooled analysis of data from three trials in the Multinational Etoricoxib and Diclofenac Arthritis Long-term (MEDAL) program. The risk for thrombotic cardiovascular events with long-term therapy was found to be similar to nsNSAID treatment (hazard ratio 0.95 ; 95\% CI 0.81, 1.11) [86]. 
nsNSAIDs

The cardiovascular safety of nsNSAIDs has been a highly contentious issue during the latter half of the last decade. A meta-analysis of randomized trials found that high-dose ibuprofen (rate ratio $1.51 ; 95 \%$ CI $0.96,2.37$ ) and highdose diclofenac (rate ratio $1.63 ; 95 \%$ CI 1.12, 2.37) were associated with a moderately increased risk of any vascular events compared with placebo, similar to that observed with COX-2-selective agents, but the risks associated with naproxen, though they cannot be completely excluded, were substantially lower (rate ratio 0.92 ; 95\% CI 0.67 , 1.26) (Fig. 4) [78]. Another systematic review and metaanalysis of controlled observational studies comparing the risks of cardiovascular events with individual NSAIDs found that diclofenac was associated with a higher risk of cardiovascular events (RR 1.40; 95\% CI 1.16, 1.70) than ibuprofen (RR 1.07; 95\% CI 0.97, 1.18) and naproxen (RR $0.97 ; 95 \%$ CI $0.87,1.07$ ) [87]. This issue has been further complicated by evidence from pharmacokinetic studies suggesting an interaction between ibuprofen and aspirin that results in reduced platelet inhibition by aspirin [88]. However, overall, there is a lack of long-term studies that have evaluated both gastrointestinal and cardiovascular events, particularly for nsNSAIDs, which may limit our understanding of the true benefits and risks of NSAIDs [33].

\section{Modern recommendations aimed at reducing NSAID toxicity}

It is important that both individual NSAID and patient risk factors should be considered in prescribing decisions.

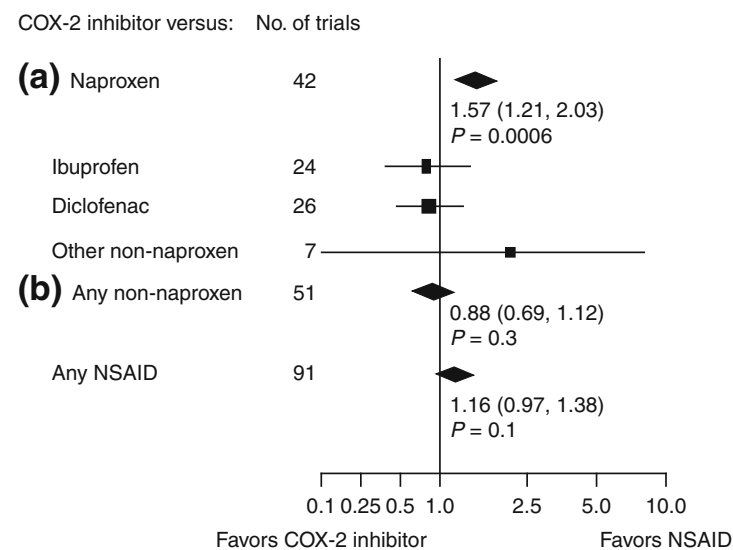

Heterogeneity between (a) and (b): $P=0.001$; between non-naproxen NSAIDs: $P=0.3$

Fig. 4 Risk of vascular events with COX-2-selective agents versus nsNSAIDs [78]. Adapted by permission from BMJ Publishing Group Limited (Kearney PM et al. BMJ; 332: 1302, copyright 2006)
Current treatment guidelines recommend that NSAIDs should be used at their lowest effective dose [5, 6, 89] and that long-term use should be avoided where possible [6, 7].

Reducing gastrointestinal risk

It is generally recommended that patients with gastrointestinal risk factors should be treated with COX-2-selective agents or nsNSAIDs plus gastroprotective co-therapy [5-7, 90, 91]. Available gastroprotective agents include $\mathrm{H}_{2}$ receptor antagonists, misoprostol, and proton pump inhibitors (PPIs). PPIs have superior efficacy to $\mathrm{H}_{2}$ receptor antagonists [92, 93], which do not provide sufficient acid suppression at traditional doses to prevent most ulcers [9496]. Compared with misoprostol, PPIs have not demonstrated superior efficacy in ulcer prevention, but they are deemed to be clinically equivalent when the safety and poor compliance issues of misoprostol are considered [97].

While it should be remembered that PPIs may not protect the lower gastrointestinal tract [47], a USA cohort study investigating ulcer-related hospitalizations found that the treatment with an nsNSAID plus a PPI was at least as effective as treatment with a COX-2-selective agent. The risk of hospitalization was reduced by $54 \%$ in patients using either NSAIDs plus PPI co-therapy or COX-2selective agents compared with NSAIDs alone [98]. A recent study compared the effects of treatment with celecoxib or diclofenac plus omeprazole for 6 months on gastrointestinal outcomes in patients with OA or RA. While no difference in incidence of hemorrhage, obstruction, or perforation between treatments was observed, a lower incidence of anemia $(\geq 20 \mathrm{~g} / \mathrm{L}$ decrease in hemoglobin or $\geq 10 \%$ decrease in hematocrit; with or without defined gastrointestinal origin) was reported with COX-2selective agent treatment compared with NSAID plus PPI [51].

A more recent concept is that of further reducing gastrointestinal risk by combining a COX-2-selective agent with a PPI, an approach that has been recommended in the UK based on national-level cost-effectiveness analyses [7, 99]. It has been demonstrated that addition of a PPI to treatment with a COX-2-selective agent significantly reduces the absolute risk of endoscopic gastric ulcers compared with placebo [100].

Although PPIs are generally considered to be well tolerated, the potential for adverse events or interactions with other therapies should be a factor in clinical decision making. For example, in a recent retrospective study, PPI therapy was associated with an increased risk of adverse cardiovascular events in aspirin-treated patients surviving 30 days after a first myocardial infarction, although this would be a population in which NSAID use would be avoided [101]. 
Despite current recommendations, evidence from observational studies suggests that as many as $60-80 \%$ of patients using NSAIDs who have gastrointestinal risk factors, including those using concomitant low-dose aspirin, do not receive appropriate gastroprotection [102, 103]. In addition, of those patients who are prescribed gastroprotective agents, more than $30 \%$ may be non-adherent, which increases their risk of gastrointestinal events [100, 104, 105]. Fixed-dose combinations of NSAIDs and gastroprotective agents have emerged as a strategy to improve adherence. For example, Arthrotec ${ }^{\circledR}$ is a combination product containing diclofenac sodium $50-75 \mathrm{mg}$ plus misoprostol $200 \mu \mathrm{g}$ that is approved for the treatment of osteoarthritis or rheumatoid arthritis in patients at high risk of developing NSAID-associated ulcers and their complications [106, 107]. More recently, a fixed-dose combination of naproxen $500 \mathrm{mg}$ and esomeprazole magnesium $20 \mathrm{mg}\left(\mathrm{VIMOVO}^{\circledR}\right)$ has been approved for the relief of signs and symptoms of OA, RA, and ankylosing spondylitis, and to decrease the risk of developing ulcers in patients at risk for developing NSAID-associated gastric ulcers [68, 108]. An additional combination therapy in development for this patient population is ibuprofen $800 \mathrm{mg}$ plus famotidine $26.6 \mathrm{mg}$ (DUEXA $^{\circledR}$ ) [109].

\section{Reducing cardiovascular risk}

The American Heart Association recommends that all NSAIDs should be used at their lowest effective dose. These and other guidelines, including those from the American College of Rheumatology, recommend that all NSAIDs, and particularly COX-2-selective agents, should be avoided where possible in patients with cardiovascular risk factors (such as hypertension, hypercholesterolemia, angina, edema, recent bypass surgery, and a history of myocardial infarction or other cardiovascular events), and should be used only when sufficient pain relief is not achieved with other therapies and the benefit outweighs the increased cardiovascular risk [74, 89-91, 110]. Where NSAID therapy is required for patients at risk of cardiovascular complications, naproxen is recommended as the NSAID of choice [74, 89-91, 110].

\section{Conclusions}

The start of the last decade saw a large increase in the use of NSAIDs following the introduction of COX-2-selective agents, which demonstrated improved gastrointestinal tolerability relative to nsNSAIDs, but concerns about their cardiovascular safety emerged and subsequently resulted in reduced use and revised thinking on the classification and safety of all NSAIDs. It is now clear that all NSAIDs are associated with varying degrees of cardiovascular and gastrointestinal risk and that individual drug and patient factors should be considered in treatment decisions.

While strategies exist to prevent complications in patients at risk of NSAID-associated gastrointestinal and cardiovascular injury, they are often underutilized or difficult to apply, particularly in patients with both types of risk factor. There remains a great need for data-driven algorithms combining cardiovascular and gastrointestinal risk that can be applied when assessing an individual patient's risk.

Acknowledgments Philip Conaghan has participated in advisory boards and presentations for, and/or holds research grants from, AstraZeneca, Bioiberica, Bristol-Myers Squibb, Centocor, Merck, Novartis, Pfizer, and Roche. The author thanks Lynsey Stevenson, from Complete Medical Communications, who provided medical writing support funded by AstraZeneca.

Open Access This article is distributed under the terms of the Creative Commons Attribution Noncommercial License which permits any noncommercial use, distribution, and reproduction in any medium, provided the original author(s) and source are credited.

\section{References}

1. Laine L (2001) Approaches to nonsteroidal anti-inflammatory drug use in the high-risk patient. Gastroenterology 120:594-606

2. Singh G (2000) Gastrointestinal complications of prescription and over-the-counter nonsteroidal anti-inflammatory drugs: a view from the ARAMIS database. Arthritis, Rheumatism, and Aging Medical Information System. Am J Ther 7:115-121

3. Bjordal JM, Ljunggren AE, Klovning A, Slordal L (2004) Nonsteroidal anti-inflammatory drugs, including cyclo-oxygenase-2 inhibitors, in osteoarthritic knee pain: meta-analysis of randomised placebo controlled trials. BMJ 329:1317

4. Altman R, Hochberg MC, Moskowitz RW, Schnitzer TJ (2000) Recommendations for the medical management of osteoarthritis of the hip and knee: 2000 update. American College of Rheumatology Subcommittee on Osteoarthritis Guidelines. Arthritis Rheum 43:1905-1915

5. Zhang W, Doherty M, Arden N, Bannwarth B, Bijlsma J, Gunther K-P, Hauselmann HJ, Herrero-Beaumont G, Jordan K, Kaklamanis P, Leeb B, Lequesne M, Lohmander S, Mazieres B, Martin-Mola E, Pavelka K, Pendleton A, Punzi L, Swoboda B, Varatojo R, Verbruggen G, Zimmermann-Gorska I, Dougados M (2005) EULAR evidence based recommendations for the management of hip osteoarthritis: report of a task force of the EULAR Standing Committee for International Clinical Studies Including Therapeutics (ESCISIT). Ann Rheum Dis 64:669-681

6. Zhang W, Moskowitz RW, Nuki G, Abramson S, Altman RD, Arden N, Bierma-Zeinstra S, Brandt KD, Croft P, Doherty M, Dougados M, Hochberg M, Hunter DJ, Kwoh K, Lohmander LS, Tugwell P (2008) OARSI recommendations for the management of hip and knee osteoarthritis, Part II: OARSI evidence-based, expert consensus guidelines. Osteoarthr Cartil 16:137-162

7. National Institute for Health and Clinical Excellence (2008) The care and management of osteoarthritis in adults. NICE clinical guideline 59. http://www.nice.org.uk/nicemedia/pdf/CG59NIC Eguideline.pdf. Accessed 17 December 2010

8. National Institute for Health and Clinical Excellence (2009) The management of rheumatoid arthritis in adults. NICE clinical 
guideline 79. http://www.nice.org.uk/nicemedia/live/12131/43327/ 43327.pdf. Accessed 4 November 2010

9. García Rodríguez LA, Barreales Tolosa L (2007) Risk of upper gastrointestinal complications among users of traditional NSAIDs and COXIBs in the general population. Gastroenterology 132:498-506

10. Merck \& Co. Inc. (2004) Merck announces voluntary worldwide withdrawal of VIOXX $^{\circledR}$. http://www.merck.com/newsroom/ vioxx/pdf/vioxx_press_release_final.pdf. Accessed 11 December 2009

11. Sun SX, Lee KY, Bertram CT, Goldstein JL (2007) Withdrawal of COX-2 selective inhibitors rofecoxib and valdecoxib: impact on NSAID and gastroprotective drug prescribing and utilization. Curr Med Res Opin 23:1859-1866

12. Greenberg JD, Fisher MC, Kremer J, Chang H, Rosenstein ED, Kishimoto M, Lee S, Yazici Y, Kavanaugh A, Abramson SB (2009) The COX-2 inhibitor market withdrawals and prescribing patterns by rheumatologists in patients with gastrointestinal and cardiovascular risk. Clin Exp Rheumatol 27:395-401

13. Schüssel K, Schulz M (2006) Prescribing of COX-2 inhibitors in Germany after safety warnings and market withdrawals. Pharmazie 61:878-886

14. Brune K, Hinz B (2004) The discovery and development of antiinflammatory drugs. Arthritis Rheum 50:2391-2399

15. Jones R (2001) Nonsteroidal anti-inflammatory drug prescribing: past, present, and future. Am J Med 110:4S-7S

16. Vane JR (2000) The fight against rheumatism: from willow bark to COX-1 sparing drugs. J Physiol Pharmacol 51:573-586

17. Vane JR, Botting RM (1998) Mechanism of action of nonsteroidal anti-inflammatory drugs. Am J Med 104(Suppl 3A): $2 \mathrm{~S}-8 \mathrm{~S}$

18. Rao PNP, Knaus EE (2008) Evolution of nonsteroidal antiinflammatory drugs (NSAIDs): cycloxygenase (COX) inhibition and beyond. J Pharm Pharmaceut Sci 11:81s-110s

19. Davies NM, Good RL, Roupe KA, Yanez JA (2004) Cyclooxygenase-3: axiom, dogma, anomaly, enigma or splice error? Not as easy as 1, 2, 3. J Pharm Pharm Sci 7:217-226

20. Day RO, Graham GG, Williams KM (1988) Pharmacokinetics of non-steroidal anti-inflammatory drugs. Clin Rheumatol 2:363-393

21. Davies NM, Anderson KE (1997) Clinical pharmacokinetics of naproxen. Clin Pharmacokinet 32:268-293

22. Davies NM, McLachlan AJ, Day RO, Williams KM (2000) Clinical pharmacokinetics and pharmacodynamics of celecoxib: a selective cyclo-oxygenase-2 inhibitor. Clin Pharmacokinet 38:225-242

23. Rainsford KD (2009) Ibuprofen: pharmacology, efficacy and safety. Inflammopharmacol 17:275-342

24. IMS Health (2008) IMS MIDAS Quantum based on selected markets (ATC $=$ M1A oral solid forms only. US\$ Actual, growth in US\$ CER.). Q4

25. Mamdani M, Rochon P, Laupacis A, Anderson G (2002) Initial patterns of use of COX-2 inhibitors by elderly patients in Ontario: findings and implications. CMAJ 167:1125-1126

26. Hawkey CJ, Cullen DJE, Pearson G, Holmes S, Doherty S, Wilson JV, Garrud P, Garner S, Maynard A, Logan RFA (2000) Pharmacoepidemiology of non-steroidal anti-inflammatory drug use in Nottingham general practices. Aliment Pharmacol Ther 14:177-185

27. Lanas A, Ferrandez A (2007) Inappropriate prevention of NSAID-induced gastrointestinal events among long-term users in the elderly. Drugs Aging 24:121-131

28. Jordan KM, Sawyer S, Coakley P, Smith HE, Cooper C, Arden NK (2004) The use of conventional and complementary treatments for knee osteoarthritis in the community. Rheumatology (Oxford) 43:381-384
29. van Staa TP, Leufkens HG, Zhang B, Smeeth L (2009) A comparison of cost effectiveness using data from randomized trials or actual clinical practice: selective cox-2 inhibitors as an example. PLoS Med 6:e1000194

30. Harris Interactive (2005) The public has doubts about the pharmaceutical industry's willingness to publish safety information about their drugs in a timely manner. http://www. harrisinteractive.com/news/printerfriend/index.asp?NewsID= 882. Accessed 14 April 2010

31. Wilcox CM, Cryer B, Triadafilopoulos G (2005) Patterns of use and public perception of over-the-counter pain relievers: focus on nonsteroidal antiinflammatory drugs. J Rheumatol 32:2218-2224

32. Chou R, Helfand M, Peterson K, Dana T, Roberts C (2006) Comparative effectiveness and safety of analgesics for osteoarthritis: comparative effectiveness review: agency for healthcare research and quality. http://effectivehealthcare.ahrq.gov/ repFiles/AnalgesicsFinal.pdf. Accessed 29 June 2010

33. Chou R, Helfand M, Peterson K, Dana T, Roberts C (2006) Drug class review of cyclo-oxygenase (COX)-2 inhibitors and nonsteroidal anti-inflammatory drugs (NSAIDs). Final report. http://www.ncbi.nlm.nih.gov/pubmed/20496448. Accessed 2 July 2010

34. Chen Y-F, Jobanputra P, Barton P, Bryan S, Fry-Smith A, Harris G, Taylor RS (2008) Cyclooxygenase-2 selective non-steroidal anti-inflammatory drugs (etodolac, meloxicam, celecoxib, rofecoxib, etoricoxib, valdecoxib and lumiracoxib) for osteoarthritis and rheumatoid arthritis: a systematic review and economic evaluation. Health Technol Assess 12:1-278

35. Singh G, Fort JG, Goldstein JL, Levy RA, Hanrahan PS, Bello AE, Andrade-Ortega L, Wallemark C, Agrawal NM, Eisen GM, Stenson WF, Triadafilopoulos G, for the SUCCESS-I Investigators (2006) Celecoxib versus naproxen and diclofenac in osteoarthritis patients: SUCCESS-I Study. Am J Med 119:255-266

36. Collantes E, Curtis SP, Lee KW, Casas N, McCarthy T, Melian A, Zhao PL, Rodgers DB, McCormick CL, Lee M, Lines CR, Gertz BJ, Etoricoxib Rheumatoid Arthritis Study Group (2002) A multinational randomized, controlled, clinical trial of etoricoxib in the treatment of rheumatoid arthritis [ISRCTN 25142273]. BMC Fam Pract 3:10

37. Gottesdiener K, Schnitzer T, Fisher C, Bockow B, Markenson J, Ko A, DeTora L, Curtis S, Geissler L, Gertz BJ, Protocol 007 Study Group (2002) Results of a randomized, dose-ranging trial of etoricoxib in patients with osteoarthritis. Rheumatology (Oxford) 41:1052-1061

38. Hunt RH, Harper S, Watson DJ, Yu C, Quan H, Lee M, Evans JK, Oxenius B (2003) The gastrointestinal safety of the COX-2 selective inhibitor etoricoxib assessed by both endoscopy and analysis of upper gastrointestinal events. Am J Gastroenterol 98:1725-1733

39. Hunt RH, Harper S, Callegari P, Yu C, Quan H, Evans J, James C, Bowen B, Rashid F (2003) Complementary studies of the gastrointestinal safety of the cyclo-oxygenase-2-selective inhibitor etoricoxib. Aliment Pharmacol Ther 17:201-210

40. Matsumoto AK, Melian A, Mandel DR, McIlwain HH, Borenstein D, Zhao PL, Lines CR, Gertz BJ, Curtis S (2002) A randomized, controlled, clinical trial of etoricoxib in the treatment of rheumatoid arthritis. J Rheumatol 29:1623-1630

41. Zacher J, Feldman D, Gerli R, Scott D, Hou SM, Uebelhart D, Rodger IW, Ozturk ZE (2003) A comparison of the therapeutic efficacy and tolerability of etoricoxib and diclofenac in patients with osteoarthritis. Curr Med Res Opin 19:725-736

42. Leung AT, Malmstrom K, Gallacher AE, Sarembock B, Poor G, Beaulieu A, Castro R, Sanchez M, Detora LM, Ng J (2002) Efficacy and tolerability profile of etoricoxib in patients with 
osteoarthritis: a randomized, double-blind, placebo and activecomparator controlled 12-week efficacy trial. Curr Med Res Opin 18:49-58

43. Matsumoto A, Melian A, Shah A, Curtis SP (2007) Etoricoxib versus naproxen in patients with rheumatoid arthritis: a prospective, randomized, comparator-controlled 121-week trial. Curr Med Res Opin 23:2259-2268

44. Bingham CO III, Sebba AI, Rubin BR, Ruoff GE, Kremer J, Bird S, Smugar SS, Fitzgerald BJ, O'Brien K, Tershakovec AM (2007) Efficacy and safety of etoricoxib $30 \mathrm{mg}$ and celecoxib $200 \mathrm{mg}$ in the treatment of osteoarthritis in two identically designed, randomized, placebo-controlled, non-inferiority studies. Rheumatology (Oxford) 46:496-507

45. Fleischmann R, Sheldon E, Maldonado-Cocco J, Dutta D, Yu S, Sloan VS (2006) Lumiracoxib is effective in the treatment of osteoarthritis of the knee: a prospective randomized 13-week study versus placebo and celecoxib. Clin Rheumatol 25:42-53

46. Moore RA, Moore OA, Derry S, Peloso PM, Gammaitoni AR, Wang H (2010) Responder analysis for pain relief and numbers needed to treat in a meta-analysis of etoricoxib osteoarthritis trials: bridging a gap between clinical trials and clinical practice. Ann Rheum Dis 69:374-379

47. Ward R (2010) Identifying and assessing benefit-risk in primary care-a family physician's perspective. Rheumatology (Oxford) 49(Suppl 2):ii18-ii23

48. Laine L (1996) Nonsteroidal anti-inflammatory drug gastropathy. Gastrointest Endosc Clin N Am 6:489-504

49. Silverstein FE, Graham DY, Senior JR, Davies HW, Struthers BJ, Bittman RM, Geis GS (1995) Misoprostol reduces serious gastrointestinal complications in patients with rheumatoid arthritis receiving nonsteroidal anti-inflammatory drugs. A randomized, double-blind, placebo-controlled trial. Ann Intern Med 123:241-249

50. Lanas A, García-Rodríguez LA, Polo-Tomás M, Ponce M, Alonso-Abreu I, Perez-Aisa MA, Perez-Gisbert J, Bujanda L, Castro M, Muñoz M, Rodrigo L, Calvet X, Del-Pino D, Garcia S (2009) Time trends and impact of upper and lower gastrointestinal bleeding and perforation in clinical practice. Am J Gastroenterol 104:1633-1641

51. Chan FK, Lanas A, Scheiman J, Berger MF, Nguyen H, Goldstein JL (2010) Celecoxib versus omeprazole and diclofenac in patients with osteoarthritis and rheumatoid arthritis (CONDOR): a randomised trial. Lancet 376:173-179

52. Laine L, Connors LG, Reicin A, Hawkey CJ, Burgos-Vargas R, Schnitzer TJ, Yu Q, Bombardier C (2003) Serious lower gastrointestinal clinical events with nonselective NSAID or coxib use. Gastroenterology 124:288-292

53. Laine L, Smith R, Min K, Chen C, Dubois RW (2006) Systematic review: the lower gastrointestinal adverse effects of nonsteroidal anti-inflammatory drugs. Aliment Pharmacol Ther 24:751-767

54. Singh G (1998) Recent considerations in nonsteroidal antiinflammatory drug gastropathy. Am J Med 105:31S-38S

55. Lanas A, Perez-Aisa MA, Feu F, Ponce J, Saperas E, Santolaria S, Rodrigo L, Balanzo J, Bajador E, Almela P, Navarro JM, Carballo F, Castro M, Quintero E (2005) A nationwide study of mortality associated with hospital admission due to severe gastrointestinal events and those associated with nonsteroidal antiinflammatory drug use. Am J Gastroenterol 100:1685-1693

56. Scheiman JM (2001) The impact of nonsteroidal anti-inflammatory drug-induced gastropathy. Am J Manag Care 7:S10-S14

57. Spiegel BMR, Farid M, Dulai GS, Gralnek IM, Kanwal F (2006) Comparing rates of dyspepsia with coxibs vs NSAID + PPI: a meta-analysis. Am J Med 119:448.e27-448.e36

58. Moskowitz RW, Abramson SB, Berenbaum F, Simon LS, Hochberg M (2007) Coxibs and NSAIDs-is the air any clearer?
Perspectives from the OARSI/International COX-2 Study Group Workshop 2007. Osteoarthr Cartil 15:849-856

59. Massó González EL, Patrignani P, Tacconelli S, García-Rodríguez LA (2010) Variability of risk of upper gastrointestinal bleeding among nonsteroidal anti-inflammatory drugs. Arthritis Rheum 62:1592-1601

60. Bombardier C, Laine L, Reicin A, Shapiro D, Burgos-Vargas R, Davis B, Day R, Ferraz MB, Hawkey CJ, Hochberg MC, Kvien TK, Schnitzer TJ, for the VIGOR Study Group (2000) Comparison of upper gastrointestinal toxicity of rofecoxib and naproxen in patients with rheumatoid arthritis. N Engl J Med 343:1520-1528

61. Laine L, Curtis SP, Cryer B, Kaur A, Cannon CP (2007) Assessment of upper gastrointestinal safety of etoricoxib and diclofenac in patients with osteoarthritis and rheumatoid arthritis in the multinational etoricoxib and diclofenac arthritis long-term (MEDAL) programme: a randomised comparison. Lancet 369:465-473

62. Schnitzer TJ, Burmester GR, Mysler E, Hochberg MC, Doherty M, Ehrsam E, Gitton X, Krammer G, Mellein B, Matchaba P, Gimona A, Hawkey CJ (2004) Comparison of lumiracoxib with naproxen and ibuprofen in the Therapeutic Arthritis Research and Gastrointestinal Event Trial (TARGET), reduction in ulcer complications: randomised controlled trial. Lancet 364:665-674

63. Silverstein FE, Faich G, Goldstein JL, Simon LS, Pincus T, Whelton A, Makuch R, Eisen G, Agrawal NM, Stenson WF, Burr AM, Zhao WW, Kent JD, Lefkowith JB, Verburg KM, Geis GS (2000) Gastrointestinal toxicity with celecoxib vs nonsteroidal anti-inflammatory drugs for osteoarthritis and rheumatoid arthritis: the CLASS study: a randomized controlled trial. Celecoxib Long-term Arthritis Safety Study. JAMA 284:1247-1255

64. Laine L, White WB, Rostom A, Hochberg M (2008) COX-2 selective inhibitors in the treatment of osteoarthritis. Semin Arthritis Rheum 38:165-187

65. Gutthann SP, Garcia Rodriguez LA, Raiford DS (1997) Individual nonsteroidal antiinflammatory drugs and other risk factors for upper gastrointestinal bleeding and perforation. Epidemiology 8:18-24

66. Huang JQ, Sridhar S, Hunt RH (2002) Role of Helicobacter pylori infection and non-steroidal anti-inflammatory drugs in peptic-ulcer disease: a meta-analysis. Lancet 359:14-22

67. Weil J, Colin-Jones D, Langman M, Lawson D, Logan R, Murphy M, Rawlins M, Vessey M, Wainwright P (1995) Prophylactic aspirin and risk of peptic ulcer bleeding. BMJ 310:827-830

68. Goldstein JL, Hochberg MC, Fort JG, Zhang Y, Hwang C, Sostek M (2010) Clinical trial: incidence of NSAID-associated endoscopic gastric ulcers in patients treated with PN 400 (naproxen plus esomeprazole magnesium) vs. enteric-coated naproxen alone. Aliment Pharmacol Ther 32:401-413

69. Ajani UA, Ford ES, Greenland KJ, Giles WH, Mokdad AH (2006) Aspirin use among US adults: behavioral risk factor surveillance system. Am J Prev Med 30:74-77

70. Goldstein JL, Lowry SC, Lanza FL, Schwartz HI, Dodge WE (2006) The impact of low-dose aspirin on endoscopic gastric and duodenal ulcer rates in users of a non-selective non-steroidal anti-inflammatory drug or a cyclo-oxygenase-2-selective inhibitor. Aliment Pharmacol Ther 23:1489-1498

71. Teoh NC, Farrell GC (2003) Hepatotoxicity associated with non-steroidal anti-inflammatory drugs. Clin Liver Dis 7:401-413

72. Aithal GP, Day CP (2007) Nonsteroidal anti-inflammatory druginduced hepatotoxicity. Clin Liver Dis 11:563-575

73. European Medicines Agency (2007) European Medicines Agency recommends withdrawal of marketing authorisations for 
lumiracoxib-containing medicines. http://www.ema.europa.eu/ pdfs/human/press/pr/PR_Lumiracoxib_57930107en.pdf. Accessed 2 July 2010

74. Antman EM, Bennett JS, Daugherty A, Furberg C, Roberts H, Taubert KA (2007) Use of nonsteroidal antiinflammatory drugs: an update for clinicians: a scientific statement from the American Heart Association. Circulation 115:1634-1642

75. FitzGerald GA (2004) Coxibs and cardiovascular disease. N Engl J Med 351:1709-1711

76. Strand V, Hochberg MC (2002) The risk of cardiovascular thrombotic events with selective cyclooxygenase-2 inhibitors. Arthritis Rheum 47:349-355

77. Warner TD, Mitchell JA (2008) COX-2 selectivity alone does not define the cardiovascular risks associated with non-steroidal anti-inflammatory drugs. Lancet 371:270-273

78. Kearney PM, Baigent C, Godwin J, Halls H, Emberson JR, Patrono C (2006) Do selective cyclo-oxygenase-2 inhibitors and traditional non-steroidal anti-inflammatory drugs increase the risk of atherothrombosis? Meta-analysis of randomised trials. BMJ 332:1302-1308

79. Bresalier RS, Sandler RS, Quan H, Bolognese JA, Oxenius B, Horgan K, Lines C, Riddell R, Morton D, Lanas A, Konstam MA, Baron JA (2005) Cardiovascular events associated with rofecoxib in a colorectal adenoma chemoprevention trial. N Engl J Med 352:1092-1102

80. Jenkins J, Seligman P (2005) Memorandum: analysis and recommendations for Agency action regarding non-steroidal antiinflammatory drugs and cardiovascular risk. FDA NDA files, pp 20-998

81. ADAPT Research Group (2006) Cardiovascular and cerebrovascular events in the randomized, controlled Alzheimer's Disease Anti-Inflammatory Prevention Trial (ADAPT). PLoS Clin Trials 1:e33

82. Bertagnolli MM, Eagle CJ, Zauber AG, Redston M, Solomon SD, Kim K, Tang J, Rosenstein RB, Wittes J, Corle D, Hess TM, Woloj GM, Boisserie F, Anderson WF, Viner JL, Bagheri D, Burn J, Chung DC, Dewar T, Foley TR, Hoffman N, Macrae F, Pruitt RE, Saltzman JR, Salzberg B, Sylwestrowicz T, Gordon GB, Hawk ET, APC Study Investigators (2006) Celecoxib for the prevention of sporadic colorectal adenomas. N Engl J Med 355:873-884

83. Arber N, Eagle CJ, Spicak J, Rácz I, Dite P, Hajer J, Zavoral M, Lechuga MJ, Gerletti P, Tang J, Rosenstein RB, Macdonald K, Bhadra P, Fowler R, Wittes J, Zauber AG, Solomon SD, Levin B, PreSAP Trial Investigators (2006) Celecoxib for the prevention of colorectal adenomatous polyps. N Engl J Med 355:885-895

84. Frampton JE, Keating GM (2007) Celecoxib: a review of its use in the management of arthritis and acute pain. Drugs 67:2433-2472

85. White WB, West CR, Borer JS, Gorelick PB, Lavange L, Pan SX, Weiner E, Verburg KM (2007) Risk of cardiovascular events in patients receiving celecoxib: a meta-analysis of randomized clinical trials. Am J Cardiol 99:91-98

86. Cannon CP, Curtis SP, FitzGerald GA, Krum H, Kaur A, Bolognese JA, Reicin AS, Bombardier C, Weinblatt ME, van der Heijde D, Erdmann E, Laine L, MEDAL Steering Committee (2006) Cardiovascular outcomes with etoricoxib and diclofenac in patients with osteoarthritis and rheumatoid arthritis in the Multinational Etoricoxib and Diclofenac Arthritis Long-term (MEDAL) programme: a randomised comparison. Lancet 368:1771-1781

87. McGettigan P, Henry D (2006) Cardiovascular risk and inhibition of cyclooxygenase: a systematic review of the observational studies of selective and nonselective inhibitors of cyclooxygenase 2. JAMA 296:1633-1644
88. Catella-Lawson F, Reilly MP, Kapoor SC, Cucchiara AJ, DeMarco S, Tournier B, Vyas SN, FitzGerald GA (2001) Cyclooxygenase inhibitors and the antiplatelet effects of aspirin. N Engl J Med 345:1809-1817

89. Desai SP, Solomon DH, Abramson SP, Buckley L, Crofford L, Cush JJ, Lovell DJ, Saag KG (2008) Recommendations for use of selective and nonselective nonsteroidal antiinflammatory drugs: an American College of Rheumatology white paper. Arthritis Rheum 59:1058-1073

90. Chan FKL, Abraham NS, Scheiman JM, Laine L (2008) Management of patients on nonsteroidal anti-inflammatory drugs: a clinical practice recommendation from the first international working party on gastrointestinal and cardiovascular effects of nonsteroidal anti-inflammatory drugs and anti-platelet agents. Am J Gastroenterol 103:2908-2918

91. Lanza FL, Chan FK, Quigley EMM (2009) Guidelines for prevention of NSAID-related ulcer complications. Am J Gastroenterol 104:728-738

92. Yeomans ND, Tulassay Z, Juhasz L, Racz I, Howard JM, van Rensburg CJ, Swannell AJ, Hawkey CJ (1998) A comparison of omeprazole with ranitidine for ulcers associated with nonsteroidal antiinflammatory drugs. Acid suppression trial: ranitidine versus Omeprazole for NSAID-associated Ulcer Treatment (ASTRONAUT) Study Group. N Engl J Med 338:719-726

93. Agrawal NM, Campbell DR, Safdi MA, Lukasik NL, Huang B, Haber MM (2000) Superiority of lansoprazole vs ranitidine in healing nonsteroidal anti-inflammatory drug-associated gastric ulcers: results of a double-blind, randomized, multicenter study. NSAID-Associated Gastric Ulcer Study Group. Arch Intern Med 160:1455-1461

94. Ehsanullah RS, Page MC, Tildesley G, Wood JR (1988) Prevention of gastroduodenal damage induced by non-steroidal anti-inflammatory drugs: controlled trial of ranitidine. BMJ 297:1017-1021

95. Robinson MG, Griffin JW Jr, Bowers J, Kogan FJ, Kogut DG, Lanza FL, Warner CW (1989) Effect of ranitidine on gastroduodenal mucosal damage induced by nonsteroidal antiinflammatory drugs. Dig Dis Sci 34:424-428

96. Taha AS, Hudson N, Hawkey CJ, Swannell AJ, Trye PN, Cottrell J, Mann SG, Simon TJ, Sturrock RD, Russell RI (1996) Famotidine for the prevention of gastric and duodenal ulcers caused by nonsteroidal antiinflammatory drugs. N Engl J Med 334:1435-1439

97. Graham DY, Agrawal NM, Campbell DR, Haber MM, Collis C, Lukasik NL, Huang B (2002) Ulcer prevention in long-term users of nonsteroidal anti-inflammatory drugs: results of a double-blind, randomized, multicenter, active- and placebocontrolled study of misoprostol vs lansoprazole. Arch Intern Med 162:169-175

98. Ray WA, Chung CP, Stein CM, Smalley WE, Hall K, Arbogast PG, Griffin MR (2007) Risk of peptic ulcer hospitalizations in users of NSAIDs with gastroprotective cotherapy versus coxibs. Gastroenterology 133:790-798

99. Latimer N, Lord J, Grant RL, O’Mahony R, Dickson J, Conaghan PG, National Institute for Health and Excellence Osteoarthritis Development Group (2009) Cost effectiveness of COX 2 selective inhibitors and traditional NSAIDs alone or in combination with a proton pump inhibitor for people with osteoarthritis. BMJ 339:b2538

100. Scheiman JM, Yeomans ND, Talley NJ, Vakil N, Chan FKL, Tulassay Z, Rainoldi JL, Szczepanski L, Ung KA, Kleczkowski D, Ahlbom H, Næsdal J, Hawkey C (2006) Prevention of ulcers by esomeprazole in at-risk patients using non-selective NSAIDs and COX-2 inhibitors. Am J Gastroenterol 101:701-710

101. Charlot M, Grove EL, Hansen PR, Olesen JB, Ahlehoff O, Selmer C, Lindhardsen J, Madsen JK, Kober L, Torp-Pedersen 
C, Gislason GH (2011) Proton pump inhibitor use and risk of adverse cardiovascular events in aspirin treated patients with first time myocardial infarction: nationwide propensity score matched study. BMJ 342:d2690

102. Abraham NS, El-Serag HB, Johnson ML, Hartman C, Richardson P, Ray WA, Smalley W (2005) National adherence to evidence-based guidelines for the prescription of nonsteroidal anti-inflammatory drugs. Gastroenterology 129:1171-1178

103. Sturkenboom MCJM, Burke TA, Dieleman JP, Tangelder MJD, Lee F, Goldstein JL (2003) Underutilization of preventive strategies in patients receiving NSAIDs. Rheumatology (Oxford) 42(Suppl 3):iii23-iii31

104. Goldstein JL, Howard KB, Walton SM, McLaughlin TP, Kruzikas DT (2006) Impact of adherence to concomitant gastroprotective therapy on nonsteroidal-related gastroduodenal ulcer complications. Clin Gastroenterol Hepatol 4:1337-1345

105. Sturkenboom MCJM, Burke TA, Tangelder MJD, Dieleman JP, Walton S, Goldstein JL (2003) Adherence to proton pump inhibitors or H2-receptor antagonists during the use of nonsteroidal anti-inflammatory drugs. Aliment Pharmacol Ther 18:1137-1147

106. Bocanegra TS, Weaver AL, Tindall EA, Sikes DH, Ball JA, Wallemark CB, Geis GS, Fort JG, for the Arthrotec Arthritis Study Group (1998) Diclofenac/misoprostol compared with diclofenac in the treatment of osteoarthritis of the knee or hip: a randomized, placebo controlled trial. J Rheumatol 25:1602-1611

107. Food and Drug Administration (FDA) (1997) Arthrotec: drug details. http://www.accessdata.fda.gov/scripts/cder/drugsatfda/ index.cfm?fuseaction=Search.DrugDetails. Accessed 3 June 2010
108. Food and Drug Administration (FDA) (2010) VIMOVO ${ }^{\mathrm{TM}}$ prescribing information. http://www.accessdata.fda.gov/drugsatfda docs/label/2010/022511lbl.pdf. Accessed 17 December 2010

109. Laine LA, Schiff M, Genovese M, Kivitz A, Tidmarsh G, Weinblatt ME (2009) Does high-dose famotidine reduce gastric and duodenal ulcers in NSAID users? Two double-blind sixmonth trials of single-tablet combination ibuprofen-famotidine vs. ibuprofen alone (Reduce-1 and 2) [abstract 407]. Gastroenterology 136(Suppl 1):A-69

110. Scheiman JM, Fendrick AM (2007) Summing the risk of NSAID therapy. Lancet 369:1580-1581

111. Facts \& Comparisons 4.0 [Online] (2009) Nonsteroidal antiinflammatory agents. http://online.factsandcomparisons.com/. Accessed 15 July 2009

112. Agrawal NG, Porras AG, Matthews CZ, Rose MJ, Woolf EJ, Musser BJ, Dynder AL, Mazina KE, Lasseter KC, Hunt TL, Schwartz JI, McCrea JB, Gottesdiener KM (2003) Single- and multiple-dose pharmacokinetics of etoricoxib, a selective inhibitor of cyclooxygenase-2, in man. J Clin Pharmacol 43:268-276

113. Brooks P, Kubler P (2006) Etoricoxib for arthritis and pain management. Ther Clin Risk Manag 2:45-57

114. Patrignani P, Capone ML, Tacconelli S (2003) Clinical pharmacology of etoricoxib: a novel selective COX2 inhibitor. Expert Opin Pharmacother 4:265-284

115. Takemoto JK, Reynolds JK, Remsberg CM, Vega-Villa KR, Davies NM (2008) Clinical pharmacokinetic and pharmacodynamic profile of etoricoxib. Clin Pharmacokinet 47:703-720 